(C) 2017, THE AUTHORS. Published by FASS and Elsevier Inc. on behalf of the American Dairy Science Association ${ }^{\circledR}$.

This is an open access article under the CC BY-NC-ND license (http://creativecommons.org/licenses/by-nc-nd/3.0/).

\title{
Milking time and risk of over-milking can be decreased with early teat cup removal based on udder quarter milk flow without loss in milk yield
}

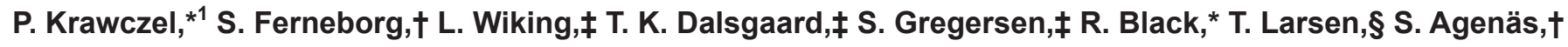 \\ K. Svennersten-Sjaunja, $\dagger$ and E. Ternman† \\ *Department of Animal Science, University of Tennessee, 2506 River Drive, 258 Brehm Animal Science Bldg., Knoxville 37996 \\ †Department of Animal Nutrition and Management, Swedish University of Agricultural Sciences, PO Box 7024, 75007 Uppsala, Sweden \\ †Department of Food Science, \\ §Department of Animal Science, Aarhus University, Foulum, Tjele DK-8830, Denmark
}

\section{ABSTRACT}

Increasing the milk flow rate at which milking is terminated can shorten milking time and increase milking efficiency. The effects on milk yield and composition have not been fully investigated when the take-off is set at the udder quarter level and independent of feeding during milking. The objective of this study was to investigate the effect of 3 take-off levels at the udder quarter level $(0.06,0.3$, and $0.48 \mathrm{~kg} / \mathrm{min})$ applied with or without feeding during milking on milking time, milk yield, the degree of udder emptying, milk composition, and free fatty acids. In this study, 30 cows were allocated into 6 groups, balanced by lactation number, lactation stage, and milk yield, and subjected to a $3 \times 2$ factorial arrangement of treatments using a Latin square design. Treatments were applied for $1 \mathrm{wk}$ each. This study demonstrated milking time could be reduced by applying up to a take-off level of $0.48 \mathrm{~kg} /$ min on udder quarter level without losing milk yield or compromising milk composition or udder health.

Key words: lactation, milk synthesis

\section{INTRODUCTION}

Using the inherent nature of the milk flow curve provides an opportunity to set the optimal termination point of an individual milking, a concept first introduced by Armstrong et al. (1970). To maximize efficiency and minimize over-milking, the termination needs to occur within the decline phase of the milk flow curve, but before the over-milking phase has begun (Tančin et al., 2006). Several studies investigated the effect of setting cluster take-off levels above 0.3 $\mathrm{kg} / \mathrm{min}$ on the whole udder level to maximize milking efficiency. Milking time decreased by approximately

Received November 16, 2016.

Accepted April 20, 2017.

${ }^{1}$ Corresponding author: krawczel@utk.edu
0.5 min with higher milk flow take-off level in studies comparing $0.8 \mathrm{~kg} / \mathrm{min}$ to 0.6 or $0.48 \mathrm{~kg} / \mathrm{min}$ (Magliaro and Kensinger, 2005) or 0.4 to $0.2 \mathrm{~kg} / \mathrm{min}$ (Rasmussen, 1993; Jago et al., 2010). A $2.5 \%$ reduction in milk yield was evident between 0.8 and $0.48 \mathrm{~kg} / \mathrm{min}$, but no effect on milk yield was observed in the other comparisons. Besier and Bruckmaier (2016) recently proposed that teat cup detachment levels of up to $1.0 \mathrm{~kg}$ of milk/ min could be applied in cluster milking with minimal loss in milk yield and significantly lower milking times compared with $0.2 \mathrm{~kg} / \mathrm{min}$. This response was based on simulated take-off levels. The critical limitation across these studies was that the termination of milking was set at the udder level. This may still allow for some individual quarters to be over- or undermilked. Overmilking causes discomfort and damage to the tissue in the teat (Neijenhuis et al., 2001; Berglund et al., 2002), and thereby, increases the risk of mastitis (Natzke et al., 1982; Rasmussen, 2004).

Although optimizing the milking termination point affects efficiency of the milking unit (MU), cow- or management-based factors also have an effect (Deming et al., 2013). For example, the practice of providing a teaser feed ration of concentrate in the automatic milking station (AMS) was recommended to motivate cows to enter the milking station (Prescott et al., 1998) and reduce variation in milking intervals. However, few empirical data demonstrate the effect of this recommendation in AMS on the efficiency of the MU and voluntary visits to the MU (Halachmi et al., 2005). Moreover, the possibility of combining a higher take-off level at the udder quarter level with feeding during milking has not been tested.

Milk fat globule (MFG) size is affected by the duration of milk accumulation (Dutreuil et al., 2016) and also the completeness of milk removal, as the largest MFG are found in the residual milk (Kernohan and Lepherd, 1969). Larger MFG are more sensitive to breakage and lipolysis (Wiking et al., 2003), and a positive relationship is present between increased milk fat 
production and MFG size (Wiking et al., 2004). However, no studies have been performed on the connection between milk removal and milk fat quality.

Our previous research observed that increasing cluster take-off level to $0.8 \mathrm{~kg} / \mathrm{min}$, decreased milking time, compared with a take-off level of $0.2 \mathrm{~kg} / \mathrm{min}$ (Ferneborg et al., 2016). Our current understanding of the effect of take-off level on milk production, udder health, and its interaction with feeding during milking is based on the response at the udder level. This approach fails to capitalize on the ability to remove teat cups at quarter level in AMS. To evaluate the possible relationship between providing teaser feed and take-off level, our specific objective was to investigate the effect of 3 take-off levels at the udder quarter level applied in combination with or without teaser feed, on milking efficiency, milk composition, free fatty acids (FFA), and MFG. Our hypothesis was that a higher take-off level applied at the udder quarter level increases milking efficiency without affecting milk yield, if it is combined with a teaser feed.

\section{MATERIALS AND METHODS}

The study was conducted at the Swedish Livestock Research Centre, SLU, Uppsala, Sweden, and all animal handling was approved by the local Animal Ethics Committee.

\section{Animals and Housing}

The study included 30 dairy cows (Swedish Red, n $=21$; Swedish Holstein $\mathrm{n}=9$ ) with average lactation number $2.9 \pm 1.5,142 \pm 25 \mathrm{DIM}$, and $34.0 \pm 11.7 \mathrm{~kg}$ of milk production per day (mean $\pm \mathrm{SD}$ ). All cows included had SCC $<115,000$ cells $/ \mathrm{mL}$ at the udder level at the start of the study. They were housed in a loose housing system (DeLaval FeedFirst, DeLaval International AB, Tumba, Sweden) with concrete alleyways and rubber mats and chopped straw bedding in cubicles. Water and silage were provided ad libitum and concentrate was provided in separate feeding stations, in a ration based on milk yield according to the NorFor system (Volden, 2011).

\section{Experimental Design}

Cows were allocated into 6 groups balanced according to lactation number, DIM, and milk yield, then subjected to a $3 \times 2$ factorial arrangement of treatments in a Latin square design. The treatments were take-off level at flow: $0.48 \mathrm{~kg}$ of milk/min (0.48), 0.3 $\mathrm{kg}$ of milk/min (0.3), or $0.06 \mathrm{~kg}$ of milk/min (0.06) on individual quarters, combined with feeding dur- ing milking or no feeding during milking. The teaser feed ration was up to $2.6 \mathrm{~kg}$ of concentrate per cow at each milking and the amount fed was deducted from the daily allowance for each cow. There were in total 6 treatment periods. Each treatment period was $7 \mathrm{~d}$ long and measurements were made during the last 2 d of each period. Milk yield, peak and average flow, milking interval, and milking time were automatically recorded by the DelPro system (DeLaval International AB, Tumba, Sweden) for each cow during each milking throughout the whole experiment and data from the last $2 \mathrm{~d}$ of each treatment period were used for evaluation of treatment effects.

Milking was performed in an automatic milking system (DeLaval VMS Voluntary Milking System, DeLaval International $\mathrm{AB}$ ) with system vacuum level set at 44 $\mathrm{kPa}$, pulsation rate 60 cycles/min, and pulsation ratio 65:35. Flow rate was measured individually from each teat by the built-in flow meters using near-infrared light to estimate the milk flow; tube length from each teat cup to the flow meters was $3.8 \mathrm{~m}$. Prestimulation consisted of cleaning of the teats with water for $8 \mathrm{~s}$, forestripping for $1 \mathrm{~s}$, and drying for $3 \mathrm{~s}$, which is the standard setting for the AMS used. Attachment of teat cups was performed on quarter level with the attachment order of right rear, left rear, right front, and left front teat. Take-off occurred on the quarter level, when the flow was below the set level for $6 \mathrm{~s}$, as programmed by the VMS. Milking permission was granted by the milking system after $6 \mathrm{~h}$ and cows were brought to the waiting area when the milking interval exceeded $8 \mathrm{~h}$, hourly except during the night (2300-0600 h).

\section{Milk Sampling and Storage}

During the last $2 \mathrm{~d}$ (d 6 and 7 ) of each treatment period, milk samples were collected during each milking of all cows. Samples from both days were analyzed for fat, protein, and lactose content, and SCC. Additional samples were collected from 1 milking between 0600 and $0000 \mathrm{~h}$ on $\mathrm{d} 6$ for analysis of MFG size distribution, milk fat globule membrane (MFGM) stability, and FFA content. In addition, residual milk removal was performed after the last milking in treatment periods 1,3 , and 5 . Residual milk was harvested through intramuscular injection of $70 \mathrm{IU}$ of oxytocin [Partoxin vet, Pharmaxim AB, Helsingborg, Sweden; $17 \mu \mathrm{g}$ (10 $\mathrm{IU}) / \mathrm{mL}$ ] directly after milking. Milking was initiated again 3 min after the injection, using a bucket milking machine. Samples for milk composition and determination of SCC were preserved with bronopol (2-bromo2-nitropropane-1.3-diol, VWR International AB, Stockholm, Sweden) and kept at $4^{\circ} \mathrm{C}$ until analysis within 5 d. Samples for MFG size and stability analysis were 
kept at $4^{\circ} \mathrm{C}$ until analysis, and samples for analysis of FFA and milk fatty acid profile were frozen 46 to $50 \mathrm{~h}$ after collection and kept at $-20^{\circ} \mathrm{C}$ until analysis.

\section{Milk Analyses}

Milk composition (fat, protein, and lactose content) was analyzed using mid-infrared spectroscopy and milk SCC was determined using flow cytometer cell counting [Fourier Transform Instrument, FT 120 and Fossomatic, FOSS, Hillerød, Denmark, respectively, for the first 2 treatment periods and CombiScope FTIR 300HP (Delta Instruments, Drachten, the Netherlands) for the samples from the remaining 4 periods]. To determine the FFA content, a recently validated method based on an in-solution derivatization of milk was used (Amer et al., 2013).

The size distribution of MFG was analyzed by integrated light scattering using a Mastersizer 2000 (Malvern Instruments Ltd., Malvern, UK) according to Wiking et al. (2004). The activity of the MFGM protein $\gamma$-glutamyl transpeptidase was examined as described by Wiking et al. (2004), BHB content was analyzed using fluorometric determination (Larsen and Nielsen, 2005), and cholesterol was determined using the method described by Larsen (2012).

\section{Data Analysis}

For all analyses, the individual cow served as the experimental and observational unit. Harvested milk samples and residual milk samples were analyzed separately. The data were analyzed by ANOVA for a $6 \times 6$ Latin square with a $2 \times 3$ factorial arrangement of treatments in a linear mixed-effects model using repeated measures in the statistical software SAS (version 9.4, SAS Institute Inc., Cary, NC). Milk composition variables, including milk yield, milking interval, milking time, SCC, and fat, were analyzed using fixed effects of breed (Swedish Red, Swedish Holstein), DIM, parity (primiparous, multiparous), visits to VMS within a day, take-off $(0.06,0.3,0.48)$, feed availability (feed, no feed), and the interaction of take-off level and feed availability. Group, week, group $\times$ week $\times$ take-off $\times$ feeding, and cow within group $\times$ week $\times$ take-off $\times$ feeding were considered random effects. Milk composition variables, including protein and lactose, were analyzed using fixed effects of breed (Swedish Red, Swedish Holstein), DIM, parity (primiparous, multiparous), visits to VMS within a day, take-off $(0.06,0.3,0.48)$, feed availability (feed, no feed), and the interaction of takeoff level and feed availability. Group, week, group $\times$ week $\times$ take-off $\times$ feeding, and cow within group $\times$ week $\times$ take-off $\times$ feeding were considered random effects. Cow within group $\times$ week $\times$ take-off $\times$ feeding was included as the subject of the repeated measure using an autoregressive covariate structure with visit serving as the repeated measure. Daily sums were calculated for milk yield, protein, and SCC, and analyzed using breed, DIM, parity, feed availability, and the interaction of takeoff level and feed availability as fixed effects. Group, week, group $\times$ week $x$ take-off $\times$ feeding, and cow within group $\times$ week $\times$ take-off $\times$ feeding were considered random effects. Additional daily sums for fat and lactose were calculated and analyzed using breed, DIM, parity, takeoff level, feed availability, and the interaction of takeoff level and feed availability as fixed effects. Group, week, group $\times$ week $\times$ take-off $\times$ feeding, and cow within group $x$ week $x$ take-off $x$ feeding were considered random effects. Cow within group $\times$ week $x$ take-off $\times$ feeding was included as the subject of the repeated measure using an autoregressive covariate structure with date serving as the repeated measure. Analyses for residual milk characteristics (SCC, protein, fat, and lactose), total FFA, fat characteristics (volumetric mean: $\mathrm{D}[4,3]$, $\mathrm{D}[0.1], \mathrm{D}[0.9]$, cholesterol, and $\mathrm{BHB}$ ), flow rate, peak flow, activity of $\gamma$-glutamyl transpeptidase in $40 \mu \mathrm{L}$ of milk, and average activity of $\gamma$-glutamyl transpeptidase included breed, DIM, parity, take-off level, feed availability, and the interaction of take-off level and feed availability, and breed and take-off as fixed effects. Group, week, group $\times$ week $\times$ take-off $\times$ feeding, and cow within group $\times$ week $\times$ take-off $\times$ feeding were considered random effects. Quarter characteristics, including protein, fat, lactose, fat characteristics $(\mathrm{D}[4,3]$, $\mathrm{D}[0.1], \mathrm{D}[0.9]$, cholesterol, and BHB), total FFA, flow rate, peak flow, activity of $\gamma$-glutamyl transpeptidase in $40 \mu \mathrm{L}$ milk, and average activity of $\gamma$-glutamyl transpeptidase included breed, DIM, parity, quarter (right front, left front, right rear, left rear), take-off level, feed availability, and the interaction of take-off level and feed availability as fixed effects. Group, group $\times$ take-off $\times$ feeding, and cow within group $\times$ take-off $\times$ feeding were considered random effects. Data on FFA content and SCC were $\log _{10}$ transformed before analysis due to nonnormal distribution. Differences in milk composition between harvested milk samples and residual milk samples were evaluated with a Student's $t$-test.

Values presented are least squares means \pm standard error of the mean unless otherwise stated. KenwardRoger's approximation for distribution of degrees of freedom between fixed effects was used, and treatment effects were declared significant at $P \leq 0.05$ and a trend was assumed for probabilities $P<0.1$ and $P>0.05$. Posthoc means separation for significant main effects was done using Tukey-Kramer's adjustment of probability values. 


\section{RESULTS}

\section{Management, Milk Flow, and Milk Yield}

Milking interval for the study was below $8 \mathrm{~h}$ for all treatments and was not affected by take-off level or teaser feed (Table 1). Milking time was shortest for 0.48 $(6.7 \pm 0.5 \mathrm{~min})$ and increased with a lower take-off level $(P<0.014): 7.2 \pm 0.5 \mathrm{~min}$ for 0.3 and $7.6 \pm 0.5 \mathrm{~min}$ for 0.06 . Milking time was not affected by provision of teaser feed and no interaction was observed between feed and take-off level on milking time (Table 1). Milk yield was greater in multiparous than primiparous cows $(29.9 \pm 1.5$ and $24.6 \pm 1.7 \mathrm{~kg}$ of milk per day respectively, $P<0.001$ ), but milk yield, peak milk flow, or average milk flow were not affected by take-off level or teaser feed (Table 1). No carry-over effects were evident for data on milking interval, milk flow, milk yield, or any other variables tested.

\section{Milk Composition}

No significant differences were observed among takeoff levels, the inclusion of teaser feed, or the interaction between them on milk composition (Table 1).

Milk fat content and milk protein content increased with increasing DIM $(P<0.05)$. Milk protein concentration $(\%$ of $\mathrm{g} / \mathrm{d})$ was greater for primiparous cows compared with multiparous cows $(3.74 \pm 0.17 \%$ and $3.41 \pm 0.12 \%$, respectively; $P<0.05)$. SCC was not affected by treatment.

No effects of treatments were found on MFG size characteristics, $\gamma$-glutamyl transpeptidase, cholesterol, or BHB (Table 2). An interaction effect was observed of breed and take-off $(P=0.001)$ for the MFG distribution $\mathrm{D}[0.1]$, indicating that the $\mathrm{D}[0.1]$ for Holstein were smaller in 0.06 than in 0.48 . For Holstein cows, the $10 \%$ of the smallest MFG in 0.48 were larger than the corresponding MFG in 0.06, 0.3, and 0.48 for Swedish Red. The $\mathrm{D}[0.1]$ for the MFG in Holstein were smaller than $2.07,2.22$, and $2.47 \pm 0.9$ for treatments 0.06 , 0.3 , and 0.48 , respectively. The $\mathrm{D}[0.1]$ for the $\mathrm{MFG}$ in the Swedish Red were smaller than 2.17, 2.20, and $2.12 \pm 0.72$ for treatments $0.06,0.3$, and 0.48 , respectively. A significant effect was found of take-off on total FFA content, with 0.48 producing lower FFA content compared with 0.3 and 0.06 . However, no effect was observed of feeding during milking on FFA content.

\section{Residual Milk}

Results on yield and composition of residual milk, based on samples collected in experimental periods 1,3 , and 5, are shown in Table 3. Residual milk, yields and

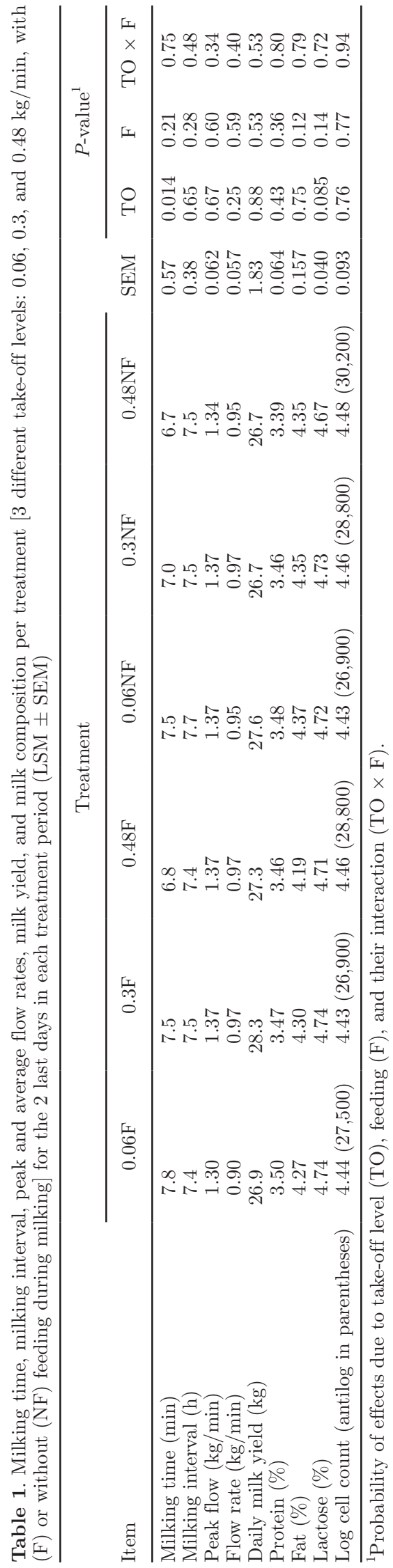

Journal of Dairy Science Vol. 100 No. 8, 2017 


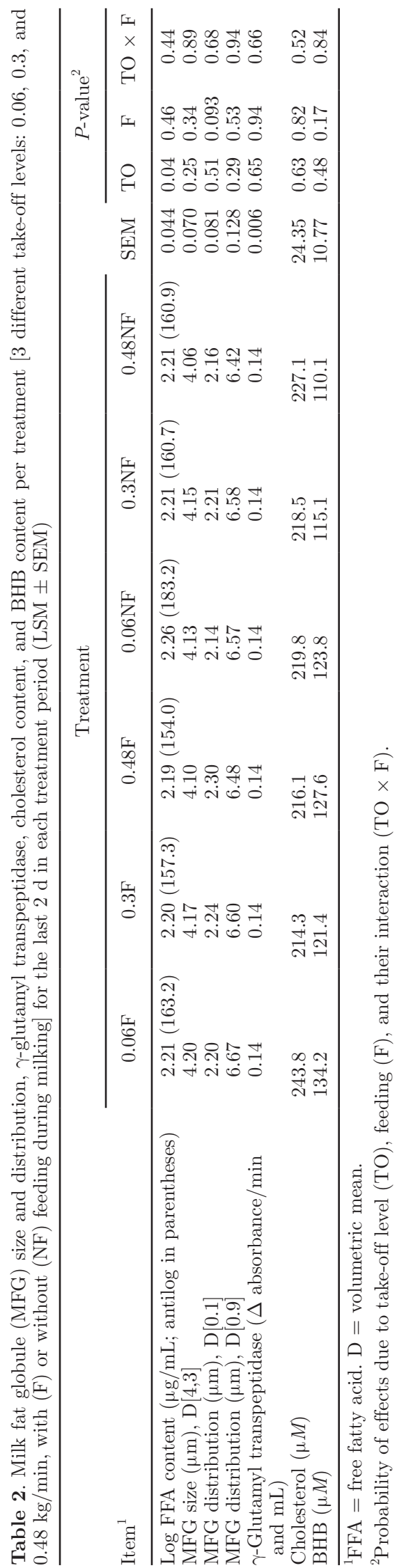

percentage of available milk yield, were not affected by take-off level, feed availability, or their interaction.

\section{DISCUSSION}

The results from this study indicated no differences in harvested milk yield, milk composition, or milk fat characteristics among the tested take-off levels with or without teaser feed. Also, no differences were observed in residual milk measured as yield and percentage of available yield. This contradicts the hypothesis of the study in the sense that the teaser feed ration was not necessary to achieve a complete udder emptying at a higher take-off level. It also contradicts previous findings on the effect of feeding during milking on milk flow and milking time (Samuelsson et al., 1993). All results on breed differences for milk yield and composition were expected and were in line with typical breed characteristics (Växa Sverige, 2016). No effect was observed of treatment on SCC, indicating no effects on udder health, which agreed with the results from Edwards et al. (2013a). However, treatment periods were short, which may not have allowed enough time for possible damages to teat ends or IMI to develop. The results are very promising as they suggest a possibility to shorten milking time, which should increase milking efficiency and decrease risk of damaging the tissue of the teats from over-milking. It is hypothesized that the milk flow curves in the present study had such a steep enough decline that resulted in actual take-off level at similar flows, regardless of settings for take-off, due to the requirement of remaining below the target take-off level for $6 \mathrm{~s}$ to initiate teat cup removal. However, actual flow at take-off is not provided by the DelPro system and was not available for evaluation.

The difference of almost $0.5 \mathrm{~min}$ per take-off level in total milking time is valuable in terms of efficiency within the MU and would allow for more milkings per day. Assuming a typical AMS herd of 60 cows milked 2.5 times per day, 1 min shorter milking time saves a total of 150 min per day. With an average milking time of $7 \mathrm{~min}$, this would allow another 21 milkings per day and the number of cows milked per hour would increase by 1 , from 7.5 to 8.5 , reducing time in the waiting area for all cows in the system. With the design of the current study, a response in milking frequency was not possible. Cows were not allowed milking permission until $6 \mathrm{~h}$ since the previous milking and were brought to milking if $8 \mathrm{~h}$ had passed. The results on milking time are in line with our previous finding (Ferneborg et al., 2016), where a milking time reduction of 1 min was achieved between take-off levels of 0.8 and $0.2 \mathrm{~kg} / \mathrm{min}$ on the whole udder level. It is also consistent with the existing literature where increasing take-off level by at 
least $0.2 \mathrm{~kg} / \mathrm{min}$ on the udder level reduced total milking time (Rasmussen, 1993; Magliaro and Kensinger, 2005; Jago et al., 2010).

The current study was conducted in an AMS system with sequential attachment of teat cups, meaning that teat cups are attached at different times for each quarter. This does, according to Bruckmaier et al. (2001), not affect milk ejection or milk removal. However, it could affect the potential for shortening milking time, since the last quarter detached determines total milking time for all quarters. In our previous study, which was performed on whole udder level using the same approach to attachment of teat cups, a similar reduction in milking time from increasing the take-off level as in the current study occurred (Ferneborg et al., 2016). In previous studies, conducted with conventional cluster milking (Edwards et al., 2013a,b), the time reduction from increasing the take-off level was slightly higher than in our current and previous research, which may indicate that the sequential teat cup attachment affects the total time saved from increasing the take-off level. However, sequential attachment is standard procedure in quarter milking, and our results are, therefore, representative for these milking systems and still reflect a meaningful amount of time saved per milking. Despite the limitations in potential to shorten milking time, quarter level milking reduces or eliminates over-milking (Weiss and Worstorff, 2001), resulting in a lower tissue load (Hillaerton et al., 2002), which is a clear benefit from increasing the take-off level. When over-milking is decreased, the risk of teat damage is also, reducing the risk of IMI (Natzke et al., 1978).

It has been suggested that the primary motivation for cows to enter the AMS is the teaser feed (Prescott et al., 1998). The current study was conducted in a FeedFirst cow traffic system, which may have reduced the efficacy of the use of feed as a stimulant for visiting the MU, oxytocin release, and milk removal, due to the likelihood that feed was consumed shortly before the VMS was visited. The effect of short time between the most recent feed intake or access to fresh grass on the response to a teaser feed, where the response is smaller with shorter time gap, has been shown by Brandsma (1978) and Samuelsson et al. (1993). Despite this, there are practical applications for determining the role of teaser feed within this approach to cow traffic, since the FeedFirst system, or other similar systems requiring cows to pass through the feeding area before entering the AMS, is commonly used, and the dynamic between the efficiency of milking and teaser feed in the AMS is not fully understood. In the current study, cows often came from the feeding area to the MU, but they were also fetched from the resting area or had spent time in the waiting area before they were milked. The study de- 
sign did not control the time between eating and when cows received the teaser feed, which may have affected the results. The results of the current study regarding effect of teaser feed are likely not applicable for other possible cow traffic systems because it is possible that the response to the teaser feed would be different in free flow or milking first traffic patterns.

Milking intervals were very restricted in this study, due to the goal of keeping milking intervals even among cows and treatments as a means to reduce the sources of variation, mainly for milk fat parameters. If milking permissions were less restricted, an effect on milking interval from the teaser feed may have been evident. This would be in line with the results from Prescott et al. (1998), who observed an increased milking frequency when teaser feed was provided in the MU.

In addition to milk ejection and yield, the behavior of the cows in response to teaser feed may have influenced the milk components. Oxytocin needs to be continuously elevated during milking for complete milk removal (Bruckmaier et al., 1994). Cows may have been frustrated if they finished the teaser feed ration before milking finished, or in the absence of a teaser ration. Anecdotally, it was noted that cows became more active in the milking station upon completion of their allocation of teaser ration and those cows who did not receive a teaser ration were also more active. This frustration might have caused an earlier interruption of oxytocin release for cows not receiving teaser feed, which could possibly explain the numerically lower milk fat content in residual milk from cows who received teaser feed because milk fat content increases during milk removal (Ontsouka et al., 2003). However, this information was not collected systematically and could, therefore, not be included in the statistical analysis. Step data when in the MU, provided by activity meters, combined with data detailing milking performance and feeding behavior would provide insight into these potential effects of teaser rations within the AMS and should be done in future studies. It is also possible that the reciprocally higher lactose content was a concentration effect due to lower milk fat. The study included only mid-lactation cows, so results on the effect of DIM should interpreted with caution.

Consistent with the lack of treatment effect on milk fat content, no effect was observed on MFG size, or MFGM composition (cholesterol and $\gamma$-glutamyl transpeptidase), supporting the interpretation that the same milk fraction was harvested regardless of take-off level. An effect on BHB could have indicated an effect on milk fatty acid synthesis because BHB is an essential part of the de novo milk fatty acid synthesis (Harvatine et al., 2009). Thus, the lack of treatment effects on BHB also indicates a lack of treatment effects on de novo milk fatty acid synthesis, which was expected. However, a lower FFA content in 0.48 compared with lower take-off levels was observed, which was likely to be due to increased exposure to air due to the longer milking times in lower take-off treatments. Rasmussen et al. (2006) found that increasing the exposure to air increases FFA content without affecting MFG size. Previous studies of the effects of take-off levels on milk yield and milk composition reported no effect on milk fat, lactose, protein, or SCC (Edwards et al., 2013a,b). On the other hand, in our previous evaluation of take-off level at the udder level and providing feed at milking, tendencies for reduced milk fat and protein were observed (Ferneborg et al., 2016), which could have been due to the cumulative effect of udder emptying (Knight et al., 1994) and improved milk ejection (Johansson et al., 1999). In the current trial, it was anticipated that setting the take-off level at the quarter level, rather than the udder level, would increase this response, but instead our data suggest otherwise. Edwards et al. (2013a) found no effect on milk fat, protein, or SCC when altering take-off level from $0.2 \mathrm{~kg} / \mathrm{min}$ up to $0.8 \mathrm{~kg} / \mathrm{min}$ with or without prestimulation.

Because milk yield was unaffected and milking time was shortened when a higher take-off level was used, an increase in average flow was expected, but not found. This contradicts the results from Edwards et al. (2013a,b), who determined an effect on average and peak flow resulted from increasing the take-off level from 0.2 to $0.8 \mathrm{~kg} / \mathrm{min}$ on the whole udder level. The results of the current study agree with our previous results (Ferneborg et al., 2016). Evaluation of milk flow curves could have provided more detail on how cows respond to take-off level and teaser feed. However, a method robust enough for this analysis was unfortunately not available.

The results also indicate that the interaction between teaser feed, milk ejection, milk removal, and cow behavior in the MU needs to be investigated further. Future studies on effects of teaser feed in the MU should include behavioral data to establish effects of both the possible frustration when the feed ration finishes and when an expected teaser feed ration is not delivered, due to technical failure or changes in settings.

\section{CONCLUSIONS}

This study shows that it is possible to reduce milking time by applying a take-off level as high as $0.48 \mathrm{~kg} / \mathrm{min}$ on the udder quarter level without losing milk yield or compromising milk composition or udder health. The teaser feed did not affect milk yield or composition and did not interact with the take-off levels. 


\section{ACKNOWLEDGMENTS}

The study was funded by the Swedish Farmers' Foundation for Agricultural Research (Stockholm, Sweden), and conducted in collaboration with DeLaval International AB. Maria Tegevall and Christine Hultén (SLU) and Rita Albrechtsen (Aarhus University) are acknowledged for their assistance with the practical work in the study.

\section{REFERENCES}

Amer, B. N., H. C. Bertram, G. Mortensen, K. Hermansen, and T. K. Dalsgaard. 2013. Novel method for quantification of individual free fatty acids in milk using an in-solution derivatisation approach and gas chromatography mass spectrometry. Int. Dairy J. 32:199-203.

Armstrong, D. V., W. G. Bickert, J. B. Gerrish, and P. W. Spike. 1970. Automatic milking machine removal. J. Dairy Sci. 53:658.

Berglund, I., G. Pettersson, and K. Svennersten-Sjaunja. 2002. Automatic milking: Effects on somatic cell count and teat end-quality. Livest. Prod. Sci. 78:115-124.

Besier, J., and R. M. Bruckmaier. 2016. Vacuum levels and milk-flowdependent vacuum drops affect machine milking performance and teat condition in dairy cows. J. Dairy Sci. 99:3096-3102.

Brandsma, S. 1978. The relation between milking, residual milk and milk yield. Pages 47-56 in Proc. Annual Meeting Natl. Mastitis Counc. Inc. National Mastitis Council, Louisville, KY.

Bruckmaier, R. M., J. Macuhova, and H. H. D. Meyer. 2001. Specific aspects of milk ejection in robotic milking: A review. Livest. Prod. Sci. 72:169-176.

Bruckmaier, R. M., D. Schams, and J. Blum. 1994. Continuously elevated concentrations of oxytocin during milking are necessary for complete milk removal in dairy cows. J. Dairy Res. 61:323-334.

Deming, J. A., R. Bergeron, K. E. Leslie, and T. J. DeVries. 2013. Associations of housing, management, milking activity, and standing and lying behavior of dairy cows milked in automatic systems. J. Dairy Sci. 96:344-351.

Dutreuil, M., J. Guinard-Flament, M. Boutinaudand, and C. Hurtaud. 2016. Effect of duration of milk accumulation in the udder on milk composition, especially on milk fat globule. J. Dairy Sci. 99:3934-3944.

Edwards, J. P., J. G. Jago, and N. Lopez-Villalobos. 2013a. Milking efficiency for grazing dairy cows can be improved by increasing automatic cluster remover thresholds without applying premilking stimulation. J. Dairy Sci. 96:3766-3773.

Edwards, J. P., J. G. Jago, and N. Lopez-Villalobos. 2013b. Shortterm application of prestimulation and increased automatic cluster remover threshold affect milking characteristics of grazing dairy cows in late lactation. J. Dairy Sci. 96:1886-1893.

Ferneborg, S., L. Stadtmüller, J. Pickova, L. Wiking, and K. Svennersten-Sjaunja. 2016. Effects of automatic cluster removal and feeding during milking on milking efficiency, milk yield and milk fat quality. J. Dairy Res. 83:180-187.

Halachmi, I., S. Ofir, and J. Miron. 2005. Comparing two concentrate allowances in an automatic milking system. Anim. Sci. 80:339-344.

Harvatine, K. J., Y. R. Boisclair, and D. E. Bauman. 2009. Major advances in the regulation of milk fat synthesis. Animal 3:40-54.

Hillaerton,, J. E., J. W. Pankey, and P. Pankey. 2002. Effect of overmilking on teat condition. J. Dairy Res. 69:81-84.
Jago, J. G., J. L. Burke, and J. H. Williamson. 2010. Effect of automatic cluster remover settings on production, udder health, and milking duration. J. Dairy Sci. 93:2541-2549.

Johansson, B., K. Uvnäs-Moberg, C. H. Knight, and K. SvennerstenSjaunja. 1999. Effect of feeding before, during and after milking on milk production and the hormones oxytocin, prolactin, gastrin and somatostatin. J. Dairy Res. 66:151-163.

Kernohan, E. A., and E. Lepherd. 1969. Size distribution of fat globules in cow's milk during milking, measured with a Coulter counter. J. Dairy Res. 36:177-182.

Knight, C. H., D. Hirst, and R. J. Dewhurst. 1994. Milk accumulation and distribution in the bovine udder during the interval between milkings. J. Dairy Res. 61:167-177.

Larsen, T. 2012. Enzymatic-fluorometric quantification of cholesterol in bovine milk. Food Chem. 135:1261-1267.

Larsen, T., and N. I. Nielsen. 2005. Fluorometric determination of $\beta$-Hydroxybutyrate in milk and plasma. J. Dairy Sci. 88:20042009 .

Magliaro, A. L., and R. S. Kensinger. 2005. Automatic cluster remover settings affect milk yield and machine-on time in dairy cows. J. Dairy Sci. 88:148-153.

Natzke, R. P., R. Everett, and D. Bray. 1982. Effect of overmilking on udder health. J. Dairy Sci. 65:117-125.

Natzke, R. P., P. A. Oltenacu, and G. H. Schmidt. 1978. Change in udder health with overmilking. J. Dairy Sci. 61:233-238.

Neijenhuis, F., H. W. Barkema, H. Hogeveen, and J. P. T. M. Noordhuizen. 2001. Relationship between teat-end callosity and occurrence of clinical mastitis. J. Dairy Sci. 84:2664-2672.

Ontsouka, C. E., R. M. Bruckmaier, and J. W. Blum. 2003. Fractionized milk composition during removal of colostrum and mature milk. J. Dairy Sci. 86:2005-2011.

Prescott, N., T. Mottram, and A. Webster. 1998. Relative motivations of dairy cows to be milked or fed in a Y-maze and an automatic milking system. Appl. Anim. Behav. Sci. 57:23-33.

Rasmussen, M. D. 1993. Influence of switch level of automatic cluster removers on milking performance and udder health. J. Dairy Res. $60: 287-297$.

Rasmussen, M. D. 2004. Overmilking and teat condition. Pages 169175 in Proc. NMC Annual Meeting Proc., Charlotte, NC.

Rasmussen, M. D., L. Wiking, M. Bjerring, and H. C. Larsen. 2006. Influence of air intake on the concentration of free fatty acids and vacuum fluctuations during automatic milking. J. Dairy Sci. 89:4596-4605.

Samuelsson, B., E. Wahlberg, and K. Svennersten. 1993. The effect of feeding during milking on milk production and milk flow. Swedish J. Agric. Res. 23:101-106.

Tančin, V., B. Ipema, P. Hogewerf, and J. Mačuhová. 2006. Sources of variation in milk flow characteristics at udder and quarter levels. J. Dairy Sci. 89:978-988.

Växa Sverige. 2016. Milk key figures in Sweden 2016. Development and Services for farmers 2016. Accessed Apr. 2016. http://www.lrf.se/ om-lrf/organisation/branschavdelningar/lrf-mjolk/statistik/.

Volden, H. 2011. NorFor-The Nordic feed evaluation system. Wageningen Academic Publishers, Wageningen, the Netherlands.

Weiss, D., and H. Worstorff. 2001. Effects of quarter take-off with and without machine stripping under simulated automatic milking conditions. Milchwissenschaft 56:427-430.

Wiking, L., L. Björck, and J. Holm Nielsen. 2003. Influence on feed composition on stability of fat globules during pumping of raw milk. Int. Dairy J. 13:797-803.

Wiking, L., J. Stagsted, L. Björck, and J. H. Nielsen. 2004. Milk fat globule size is affected by fat production in dairy cows. Int. Dairy J. 14:909-913. 